\title{
Stimulation of Suicidal Erythrocyte Death by Artesunate
}

\author{
Kousi Alzoubi ${ }^{a}$ Salvatrice Calabròa,b Rosi Bissinger ${ }^{\mathrm{a}}$ Majed Abed ${ }^{\mathrm{a}}$ \\ Caterina Faggio ${ }^{b}$ Florian Lang $^{\text {a }}$
}

${ }^{a}$ Department of Physiology, University of Tübingen, Tübingen, Germany; ${ }^{\text {b} D e p a r t m e n t ~ o f ~ B i o l o g i c a l ~ a n d ~}$ Environmental Sciences, University of Messina, Viale Ferdinando Stagno d'Alcontres, Messina, Italy

\section{Key Words}

Phosphatidylserine $\cdot$ Artesunate $\cdot$ Calcium $•$ Ceramide $\bullet$ ROS $•$ Eryptosis

\begin{abstract}
Background: The artemisinin derivative artesunate is effective in the treatment of severe malaria and is considered for the treatment of malignancy. Artesunate triggers tumor cell apoptosis, an effect at least in part mediated by mitochondria. Even though lacking mitochondria, erythrocytes may similarly enter suicidal death or eryptosis, which is characterized by cell shrinkage and breakdown of the phospholipid asymmetry of the cell membrane with phosphatidylserine translocation to the erythrocyte surface. Triggers of eryptosis include increase of cytosolic $\mathrm{Ca}^{2+}$-activity $\left(\left[\mathrm{Ca}^{2+}\right]_{i}\right)$, ceramide formation, and oxidative stress. The present study explored whether artesunate stimulates eryptosis. Methods: Phosphatidylserine exposure at the cell surface was estimated from annexin $V$ binding, cell volume from forward scatter, $\left[\mathrm{Ca}^{2+}\right]_{i}$ from Fluo3-fluorescence, ceramide abundance from binding of specific antibodies, and oxidative stress from 2',7'-dichlorodihydrofluorescein-diacetate fluorescence. Results: A $48 \mathrm{~h}$ exposure of human erythrocytes to artesunate significantly increased the percentage of annexinV-binding cells $(\geq 9 \mu \mathrm{g} / \mathrm{ml})$ without significantly influencing forward scatter. Artesunate significantly increased $\left[\mathrm{Ca}^{2+}\right]_{i \cdot}$. The stimulation of annexin-V-binding by artesunate $(15 \mu \mathrm{g} /$ $\mathrm{ml}$ ) was significantly blunted but not abolished by removal of extracellular $\mathrm{Ca}^{2+}$. Artesunate increased the ceramide abundance at the cell surface and the $2^{\prime}, 7^{\prime}$-dichlorodihydrofluoresceindiacetate fluorescence. Conclusions: Artesunate stimulates phosphatidylserine translocation at the erythrocyte cell membrane, an effect at least partially due to increase of $\left[\mathrm{Ca}^{2+}\right]_{\mathrm{i}^{\prime}}$ stimulation of ceramide formation and generation of oxidative stress.
\end{abstract}




\section{Introduction}

Artesunate is a first line treatment for severe malaria [1-10]. Artesunate may be effective against further pathogens including viruses [11]. Beyond that, artesunate is considered for the treatment of malignancy [12-27]. Its efficacy in malignancy may at least in part result from its ability to induce tumor cell apoptosis [13, 14, 23, 25, 26, 28-31]. The proapoptotic effect has been attributed in part to mitochondria [23, 25, 29]. Artemisinin, an antimalarial drug related to artesunate, has previously been reported to inhibit erythrocyte cation channels [32].

Even though lacking nuclei and mitochondria, key organelles in the execution of apoptosis, erythrocytes may enter eryptosis, a suicidal cell death characterized by cell shrinkage [33] and cell membrane scrambling with exposure of phosphatidylserine at the cell surface [34]. Triggers of eryptosis may include increase of cytosolic $\mathrm{Ca}^{2+}$ activity $\left(\left[\mathrm{Ca}^{2+}\right] \mathrm{i}\right)[34]$, formation of ceramide [35], energy depletion [34], activated caspases [36-40], activation of casein kinase $1 \alpha[41,42]$, Janus-activated kinase JAK3 [43], protein kinase C [44], or p38 kinase [45], as well as impaired activity of AMP activated kinase AMPK [46], cGMP-dependent protein kinase [37], PAK2 kinase [47], sorafenib sensitive kinases [48], and sunitinib sensitive kinases [49]. Moreover, eryptosis is stimulated by a wide variety of xenobiotics [35, 49-79] including several natural substances [34] including gambogic acid [80], tannic acid [81], ipratropium [82], withaferin [83], tanshinone [58], thymoquinone [84], ursolic acid [85], honokiol [86], saponin [87], apigenin [88], oridonin [89], and alphalipoic acid [36].

The present study explored, whether artesunate stimulates eryptosis. To this end, human erythrocytes from healthy individuals were treated with artesunate and phosphatidylserine surface abundance, cell volume, $\left[\mathrm{Ca}^{2+}\right]_{i}$, ceramide abundance and reactive oxygen species (ROS) determined by flow cytometry.

\section{Materials and Methods}

Erythrocytes, solutions and chemicals

Fresh Lithium-Heparin-anticoagulated blood samples were kindly provided by the blood bank of the University of Tübingen. The study is approved by the ethics committee of the University of Tübingen $(184 / 2003 \mathrm{~V})$. The blood was centrifuged at $120 \mathrm{rcf}$ for $20 \mathrm{~min}$ at $23^{\circ} \mathrm{C}$ and the platelets and leukocytescontaining supernatant was disposed. Erythrocytes were incubated in vitro at a hematocrit of $0.4 \%$ in Ringer solution containing (in $\mathrm{mM}$ ) $125 \mathrm{NaCl}, 5 \mathrm{KCl}, 1 \mathrm{MgSO}_{4}, 32 \mathrm{~N}$-2-hydroxyethylpiperazine-N-2-ethanesulfonic acid (HEPES), 5 glucose, $1 \mathrm{CaCl}_{2} ; \mathrm{pH} 7.4$ at $37^{\circ} \mathrm{C}$ for $48 \mathrm{~h}$. Where indicated, erythrocytes were exposed to artesunate (Sigma Aldrich, Schnelldorf, Germany) at the indicated concentrations. Stock solutions of $100 \mathrm{mg} / \mathrm{ml}$ artesunate dissolved in DMSO were used. For comparison, the effect of DMSO similar to the highest quantity added from the stock solution was tested (0.35 $\mu \mathrm{l}$ DMSO /ml Ringer in fig.1, 2 and 0.15 $\mu \mathrm{l} \mathrm{DMSO/ml} \mathrm{Ringer} \mathrm{in} \mathrm{Fig.} \mathrm{3).}$

\section{Analysis of annexin-V-binding and forward scatter}

After incubation under the respective experimental condition, $50 \mu \mathrm{l}$ cell suspension was washed in Ringer solution containing $5 \mathrm{mM} \mathrm{CaCl}_{2}$ and then stained with Annexin-V-FITC (1:200 dilution; ImmunoTools, Friesoythe, Germany) in this solution at $37^{\circ} \mathrm{C}$ for 20 min under protection from light. In the following, the forward scatter (FSC) of the cells was determined, and annexin-V-FITC fluorescence intensity was measured with an excitation wavelength of $488 \mathrm{~nm}$ and an emission wavelength of $530 \mathrm{~nm}$ on a FACS Calibur (BD, Heidelberg, Germany).

\section{Measurement of intracellular $\mathrm{Ca}^{2+}$}

After incubation, erythrocytes were washed in Ringer solution and then loaded with Fluo-3/AM (Biotium, Hayward, USA) in Ringer solution containing $5 \mathrm{mM} \mathrm{CaCl}_{2}$ and $5 \mu \mathrm{M}$ Fluo-3/AM. The cells were incubated at $37^{\circ} \mathrm{C}$ for 30 min and washed twice in Ringer solution containing $5 \mathrm{mM} \mathrm{CaCl}_{2}$. The Fluo-3/ AM-loaded erythrocytes were resuspended in $200 \mu \mathrm{l}$ Ringer. Then, $\mathrm{Ca}^{2+}$-dependent fluorescence intensity 
was measured with an excitation wavelength of $488 \mathrm{~nm}$ and an emission wavelength of $530 \mathrm{~nm}$ on a FACS Calibur.

\section{Determination of ceramide formation}

To determine ceramide abundance, a monoclonal antibody-based assay was used. After incubation, cells were stained for $1 \mathrm{~h}$ at $37^{\circ} \mathrm{C}$ with $1 \mu \mathrm{g} / \mathrm{ml}$ anti-ceramide antibody (clone MID 15B4; Alexis, Grünberg, Germany) in phosphate-buffered saline (PBS) containing $0.1 \%$ bovine serum albumin (BSA) at a dilution of 1:10. After two washing steps with PBS-BSA, cells were stained for $30 \mathrm{~min}$ with polyclonal fluoresceinisothiocyanate (FITC)-conjugated goat anti-mouse IgG and IgM specific antibody (Pharmingen, Hamburg, Germany) diluted 1:50 in PBS-BSA. Unbound secondary antibody was removed by repeated washing with PBS-BSA. Samples were then analyzed by flow cytometric analysis at an excitation wavelength of $488 \mathrm{~nm}$ and an emission wavelength of $530 \mathrm{~nm}$.

Determination of reactive oxygen species (ROS)

ROS production was determined utilizing $2^{\prime}, 7^{\prime}$-dichlorodihydrofluorescein diacetate (DCFDA) [90]. Briefly, the cells were suspended in FACS buffer and the fluorescence was analysed with flow cytometry (FACS-calibur from Becton Dickinson; Heidelberg, Germany). DCFDA fluorescence intensity was measured in FL-1 with an excitation wavelength of $488 \mathrm{~nm}$ and an emission wavelength of $530 \mathrm{~nm}$.

\section{Statistics}

Data are expressed as arithmetic means \pm SEM. As indicated in the figure legends, statistical analysis was made using ANOVA with Tukey's test as post-test and $t$ test as appropriate; $\mathrm{n}$ denotes the number of different erythrocyte specimens studied. Since different erythrocyte specimens used in distinct experiments are differently susceptible to triggers of eryptosis, the same erythrocyte specimens have been used for control and experimental conditions.

\section{Results}

The present study was designed to possibly disclose an effect of artesunate on eryptosis, the suicidal erythrocyte death. A hallmark of eryptosis is cell membrane scrambling with phosphatidylserine translocation to the cell surface.

Binding of labeled Annexin- $\mathrm{V}$ was determined utilizing flow cytometry in order to identify phosphatidylserine exposing erythrocytes. The erythrocytes were incubated for 48 hours in Ringer solution without or with artesunate $(3-35 \mu \mathrm{g} / \mathrm{ml})$ prior to the

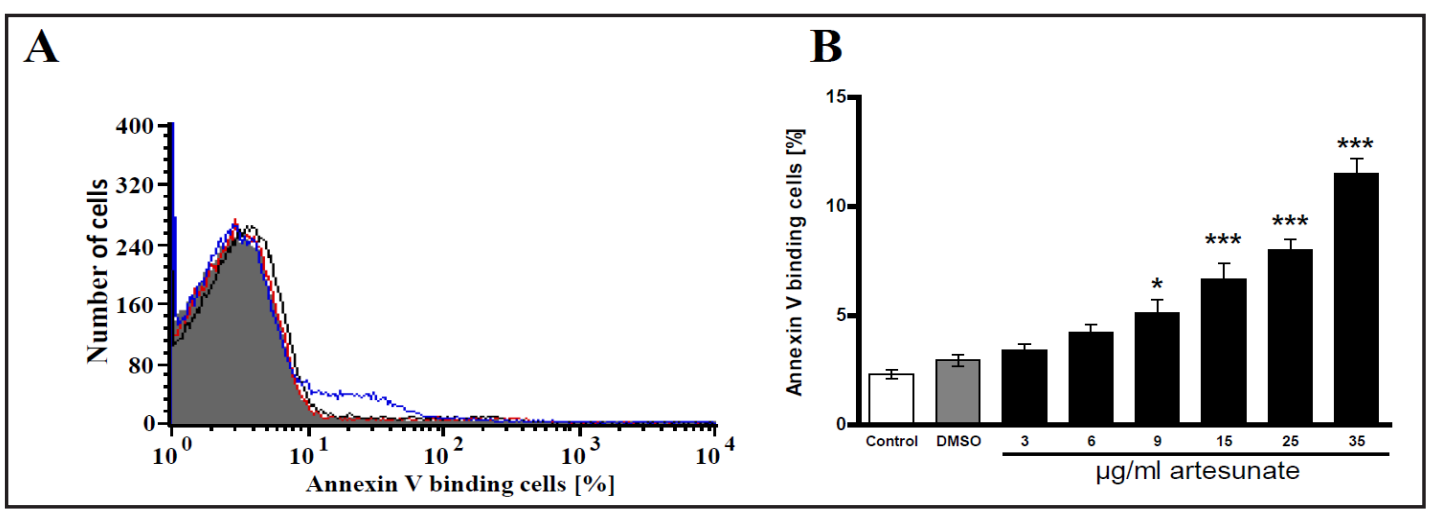

Fig. 1. Effect of artesunate on phosphatidylserine exposure. A. Original histogram of annexin-V-binding of erythrocytes following exposure for $48 \mathrm{~h}$ to Ringer solution without (grey area) and with (red, black, blue line) presence of $6,15,35 \mu \mathrm{g} / \mathrm{ml}$ artesunate respectively. B. Arithmetic means \pm SEM of erythrocyte annexinV-binding $(n=16)$ following incubation for $48 \mathrm{~h}$ to Ringer solution without (white bar) or with (black bars) presence of artesunate $(3-35 \mu \mathrm{g} / \mathrm{ml}$ ). For comparison, the effect of $0.35 \mu \mathrm{l} \mathrm{DMSO} / \mathrm{ml}$ Ringer is shown (grey bar). ${ }^{*}(\mathrm{p}<0.05),{ }^{* * *}(\mathrm{p}<0.001)$ indicate significant difference from DMSO alone (ANOVA). 


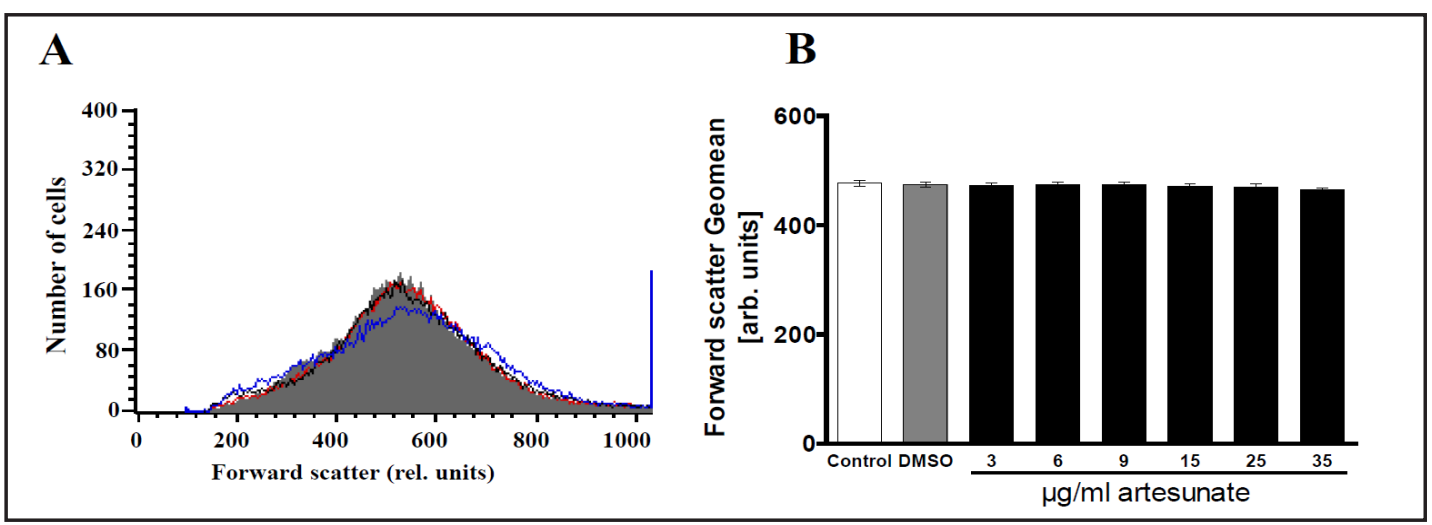

Fig. 2. Effect of artesunate on erythrocyte forward scatter. A. Original histogram of forward scatter of erythrocytes following exposure for $48 \mathrm{~h}$ to Ringer solution without (grey area) and with (red, black, blue line) presence of $6,15,35 \mu \mathrm{g} / \mathrm{ml}$ artesunate respectively. B. Arithmetic means \pm SEM $(\mathrm{n}=16)$ of the normalized erythrocyte forward scatter (FSC) following incubation for 48 h to Ringer solution without (white bar) or with (black bars) presence of artesunate $(3-35 \mu \mathrm{g} / \mathrm{ml}$ ). For comparison, the effect of $0.35 \mu \mathrm{l}$ $\mathrm{DMSO} / \mathrm{ml}$ Ringer is shown (grey bar).

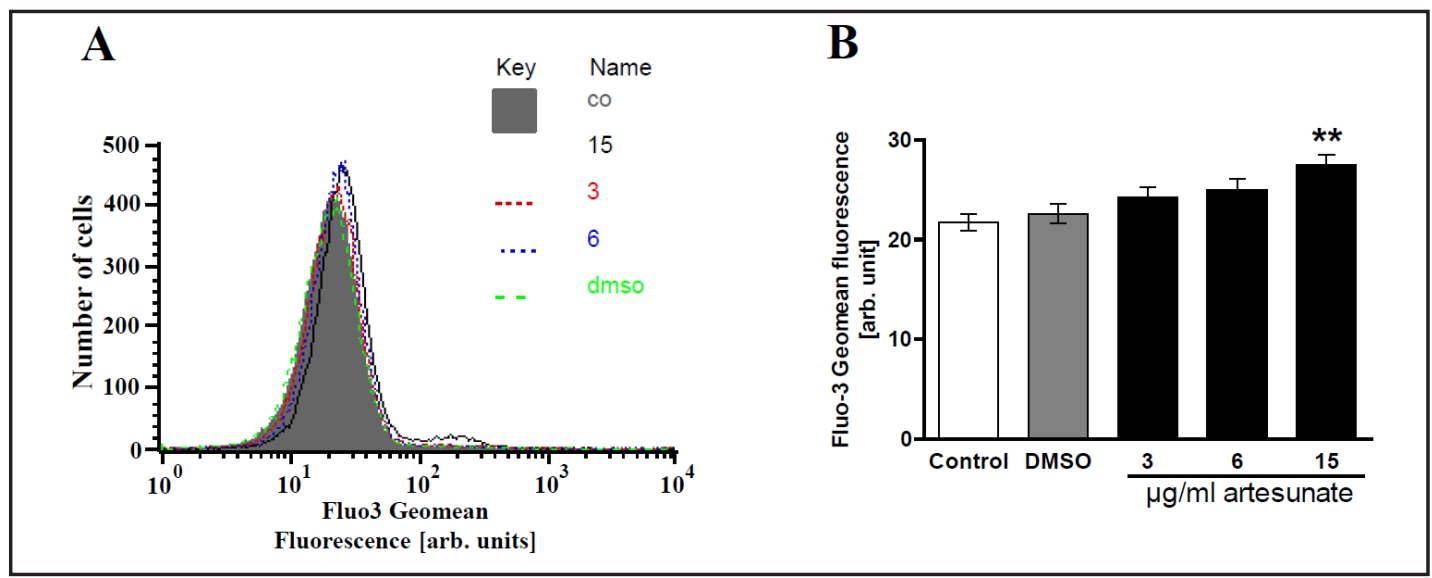

Fig. 3. Effect of artesunate on erythrocyte $\mathrm{Ca}^{2+}$ activity. A. Original histogram of Fluo3 fluorescence in erythrocytes following exposure for $48 \mathrm{~h}$ to Ringer solution without DMSO and artesunate (grey area), with DMSO (green line) and with presence of 3, 6, $15 \mu \mathrm{g} / \mathrm{ml}$ artesunate (red, blue, black line). B. Arithmetic means \pm SEM ( $\mathrm{n}=16$ ) of the Fluo3 fluorescence (arbitrary units) in erythrocytes exposed for $48 \mathrm{~h}$ to Ringer solution without (white bar) or with (black bars) presence of artesunate (3-15 $\mu \mathrm{g} / \mathrm{ml}$ ). For comparison, the effect of $0.15 \mu \mathrm{DMSO} / \mathrm{ml}$ Ringer is shown (grey bar). ${ }^{* *}(\mathrm{p}<0.01)$ indicate significant difference from DMSO alone.

measurements. As illustrated in Fig. 1, a $48 \mathrm{~h}$ exposure to artesunate enhanced the percentage of annexin-V-binding erythrocytes, an effect reaching statistical significance at $9 \mu \mathrm{g} / \mathrm{ml}$ artesunate concentration. Accordingly, artesunate treatment was followed by erythrocyte cell membrane scrambling with translocation of phosphatidylserine to the cell surface.

Alterations of cell volume were estimated from forward scatter in flow cytometry. Forward scatter was determined following a 48 hours incubation of human erythrocytes in Ringer solution without or with artesunate $(3-35 \mu \mathrm{g} / \mathrm{ml})$. As shown in Fig. 2, forward scatter tended to decrease following incubation of human erythrocytes in Ringer solution with artesunate, an effect, however, not reaching statistical significance.

In order to test whether artesunate affected cytosolic $\mathrm{Ca}^{2+}$ activity $\left(\left[\mathrm{Ca}^{2+}\right]_{\mathrm{i}}\right)$, Fluo3 fluorescence was determined in flow cytometry. As illustrated in Fig. 3, a 48 h exposure to artesunate $(3-15 \mu \mathrm{g} / \mathrm{ml})$ increased Fluo3 fluorescence, an effect reaching statistical significance at $15 \mu \mathrm{g} / \mathrm{ml}$ artesunate concentration. Thus, artesunate increased $\left[\mathrm{Ca}^{2+}\right]_{\mathrm{i}^{*}}$. 


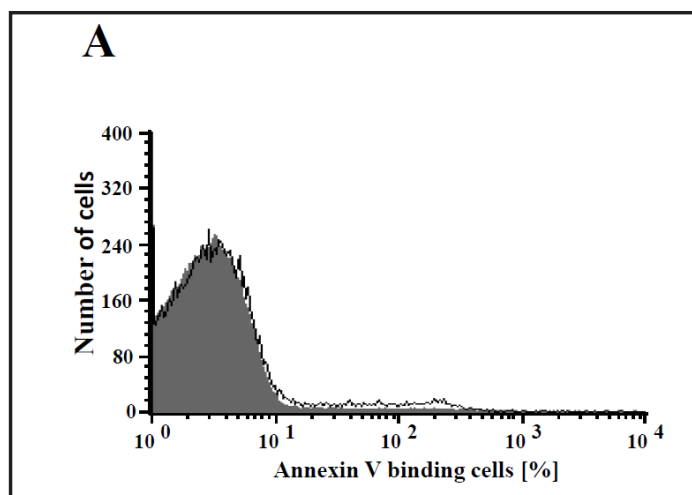

Fig. 4. $\mathrm{Ca}^{2+}$ dependence of artesunate- induced phosphatidylserine exposure. A. Original histogram of annexin-V-binding of erythrocytes following exposure for $48 \mathrm{~h}$ to $\mathrm{Ca}^{2+}$ containing Ringer solution without (grey area), or with (black line) presence of $15 \mu \mathrm{g} / \mathrm{ml}$ artesunate. B. Original histogram of annexin-V-binding of erythrocytes following exposure for $48 \mathrm{~h}$ to Ringer solution in the absence of calcium without (grey area), or with (black line) presence of $15 \mu \mathrm{g} / \mathrm{ml}$ artesunate. C. Arithmetic means \pm SEM $(n=8)$ of erythrocyte forward scatter after a $48 \mathrm{~h}$ treatment with Ringer solution without (white bars) or with (black bars) $15 \mu \mathrm{g} / \mathrm{ml}$ artesunate in the presence (left bars, $+\mathrm{Ca}^{2+}$ ) and absence (right bars, $\left.-\mathrm{Ca}^{2+}\right)$ of calcium. ${ }^{*}(\mathrm{p}<0.05),{ }^{* * *}(\mathrm{p}<0.001)$ indicates significant difference from the absence of artesunate, \#\# $(\mathrm{p}<0.01)$ indicates significant difference from the respective value in the presence of $\mathrm{Ca}^{2+}$.

\section{B}
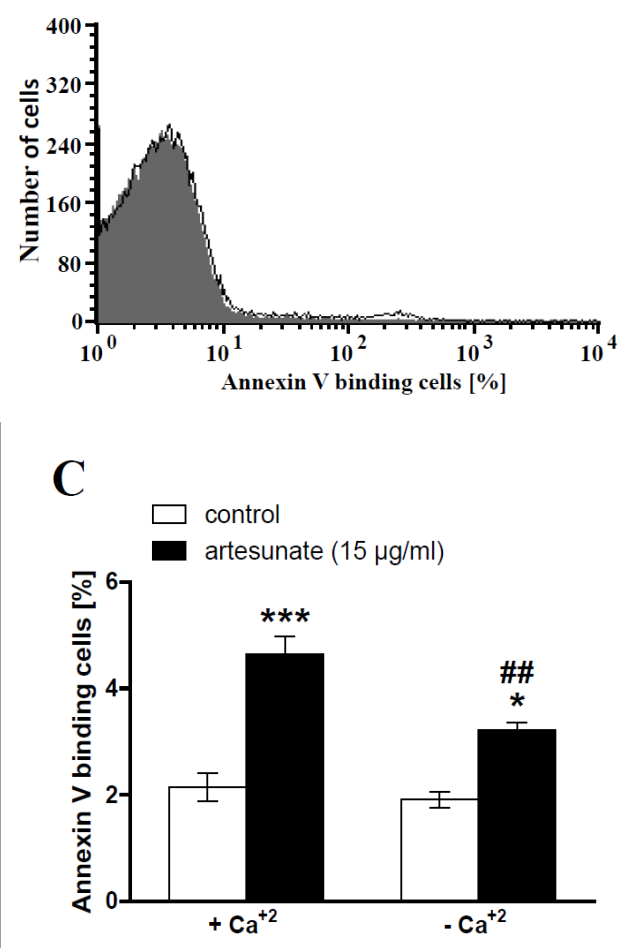

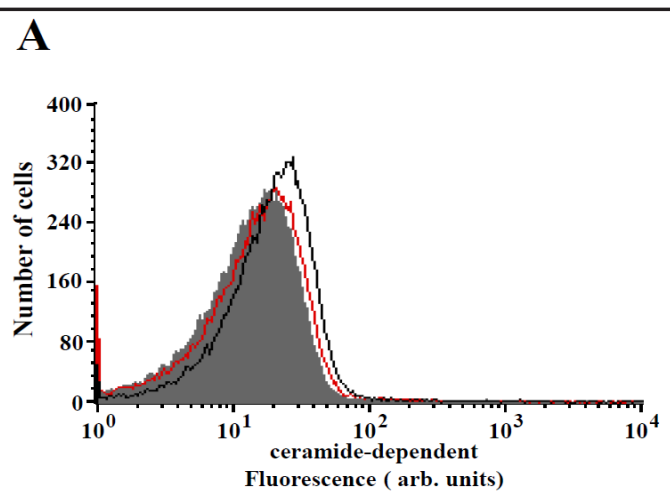

Fig. 5. Effect of artesunate on ceramide formation. A. Original histogram of ceramide surface abundance of erythrocytes following exposure for $48 \mathrm{~h}$ to Ringer solution without (grey shadow) and with (red, black line) presence of 6 or $15 \mu \mathrm{g} / \mathrm{ml}$ artesunate, respectively. B. Arithmetic means \pm SEM $(n=6)$ of ceramide abundance after a $48 \mathrm{~h}$ incubation in Ringer solution without (white bar) or with $15 \mu \mathrm{g} / \mathrm{ml}$ artesunate (black bar). ${ }^{*}(\mathrm{p}<0.05)$ indicates significant difference from the absence of artesunate $(t$ test $)$.

Additional experiments tested whether the artesunate-induced cell membrane scrambling required entry of extracellular $\mathrm{Ca}^{2+}$. To this end, erythrocytes were exposed for $48 \mathrm{~h}$ to $15 \mu \mathrm{g} / \mathrm{ml}$ artesunate in the presence or nominal absence of extracellular $\mathrm{Ca}^{2+}$. As illustrated in Fig. 4, removal of extracellular $\mathrm{Ca}^{2+}$ significantly blunted the increase of annexinV-binding following artesunate treatment. However, even in the absence of extracellular 


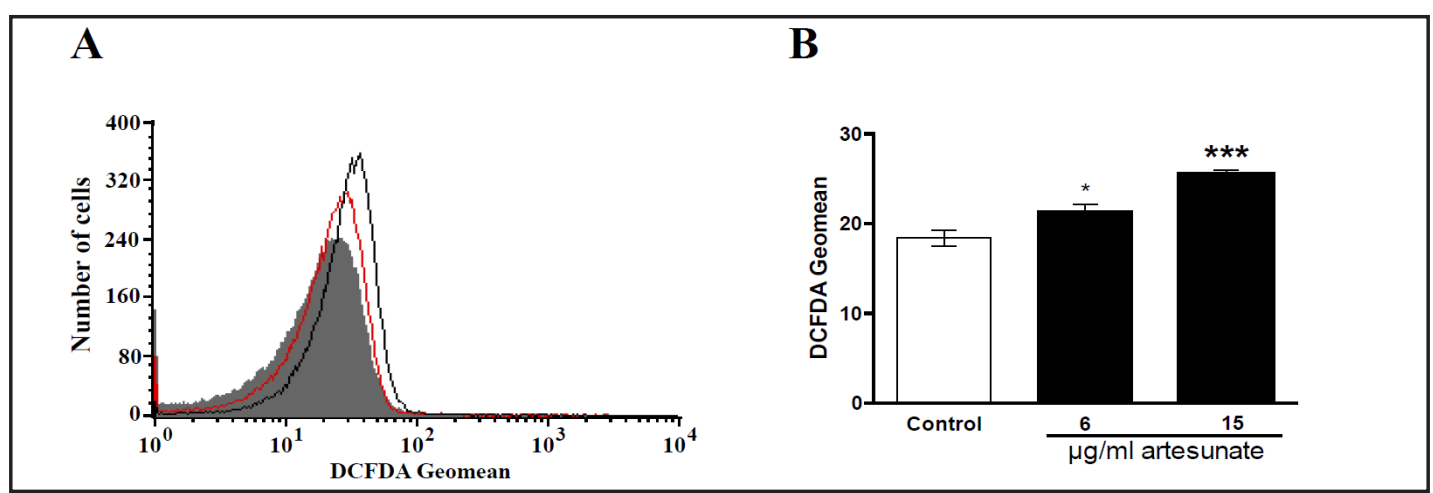

Fig.6. Effect ofartesunate on reactive oxygen species. A. Originalhistogram of 2 ' $7^{\prime}$-dichlorodihydrofluorescein diacetate (DCFDA) fluorescence in erythrocytes following exposure for 48 hours to Ringer solution without (grey shadow) and with (red, black line) presence of 6 or $15 \mu \mathrm{g} / \mathrm{ml}$ artesunate respectively. B. Arithmetic means \pm SEM $(n=6)$ of erythrocyte DCFDA fluorescence following incubation for 48 hours to Ringer solution without (white bar) or with (black bar) presence of artesunate $(6$ or $15 \mu \mathrm{g} / \mathrm{ml}) .{ }^{* * *}(\mathrm{p}<0.001)$ indicates significant difference from the absence of artesunate (paired $t$-test).

$\mathrm{Ca}^{2+}$ artesunate significantly increased the percentage of annexin-V-binding erythrocytes. Thus, the effect of artesunate on phosphatidylserine translocation was partially but not fully dependent on entry of extracellular $\mathrm{Ca}^{2+}$.

In order to test, whether artesunate-induced cell membrane scrambling was paralleled by formation of ceramide, which could trigger eryptosis without requirement of increased $\left[\mathrm{Ca}^{2+}\right]_{\mathrm{i}}$, the ceramide abundance at the erythrocyte surface was determined utilizing a specific anti-ceramide antibody. As illustrated in Fig. 5, a $48 \mathrm{~h}$ exposure of erythrocytes to $15 \mu \mathrm{g} / \mathrm{ml}$ artesunate significantly increased the abundance of ceramide at the erythrocyte surface.

Additional experiments were performed to explore whether artesunate modified the formation of reactive oxygen species (ROS). To this end, ROS was determined utilizing $2^{\prime}, 7^{\prime}$-dichlorodihydrofluorescein diacetate (DCFDA). As shown in Fig. 6, a 48 hours exposure to artesunate $(\geq 6 \mu \mathrm{g} / \mathrm{ml})$ significantly increased the DCFDA fluorescence, indicating that artesunate triggered oxidative stress.

\section{Discussion}

The present study discloses a novel effect of artesunate. The observations reveal that treatment of erythrocytes with artesunate leads to cell membrane scrambling with phosphatidylserine translocation to the erythrocyte surface. Phosphatidylserine exposure at the cell surface is the most important hallmark of eryptosis, the suicidal death of erythrocytes. The artesunate concentration $(9 \mu \mathrm{g} / \mathrm{ml})$ required for the stimulation of erythrocyte cell membrane scrambling was in the range of those approached in vivo [91].

The cell membrane scrambling following artesunate treatment is paralleled and partially caused by increase of $\left[\mathrm{Ca}^{2+}\right]_{\mathrm{i}^{\text {. }}}$ However, the increase of $\left[\mathrm{Ca}^{2+}\right]_{\mathrm{i}}$ does not fully account for the stimulation of eryptosis by artesunate, but artesunate triggered phosphatidylserine exposure even in the absence of extracellular $\mathrm{Ca}^{2+}$. Besides its effect on $\left[\mathrm{Ca}^{2+}\right]_{\mathrm{i}}$, artesunate stimulated the formation of ceramide and induced oxidative stress. Ceramide and oxidative stress are both powerful stimulators of eryptosis [34]. Artesunate has previously been shown to induce oxidative stress [92,93] and the proapoptotic effect of artesunate is inhibited by the antioxidant $\mathrm{N}$-acetyl-cysteine [94]. To the best of our knowledge, a stimulating effect of artesunate on ceramide formation has never been shown before.

Artesunate tended to decrease cell volume, an effect, however, not reaching statistical significance. Eryptotic cell shrinkage may result from increase of $\left[\mathrm{Ca}^{2+}\right]_{i}$ with subsequent 
activation of $\mathrm{Ca}^{2+}$ sensitive $\mathrm{K}^{+}$channels, $\mathrm{K}^{+}$exit, cell membrane hyperpolarization, $\mathrm{Cl}^{-}$exit and thus cellular loss of $\mathrm{KCl}$ with osmotically obliged water [33].

The physiological function of phosphatidylserine exposure at the erythrocyte surface is to trigger the elimination of defective erythrocytes and thus to protect against hemolysis [34]. Hemolysis of defective erythrocytes results in release of hemoglobin, which may be subsequently filtered at the renal glomeruli, precipitate in the acidic lumen of renal tubules and thus occlude the nephrons [95].

Eryptosis may further foster the removal of infected erythrocytes in malaria [96]. The malaria pathogen Plasmodium enters erythrocytes and induces oxidative stress on the host cell leading to activation of several ion channels of the host cell membrane including $\mathrm{Ca}^{2+}$ permeable erythrocyte cation channels $[97,98] . \mathrm{Ca}^{2+}$ entry through the unselective cation channels triggers eryptosis leading to clearance of the infected erythrocytes from circulating blood [96]. Thus, eryptosis of infected erythrocytes counteracts parasitemia and may thus favourably influence the clinical course of malaria [96]. Along those lines, several genetic erythrocyte disorders including sickle-cell trait, beta-thalassemia-trait, homozygous $\mathrm{Hb}-\mathrm{C}$ and homozygous G6PD-deficiency foster eryptosis and thus protect against a severe course of malaria [34, 99-101]. The same holds for clinical conditions with accelerated eryptosis, such as iron deficiency [102]. Moreover, several xenobiotics triggering eryptosis including lead [103], chlorpromazine [104] or NO synthase inhibitors [105] have previously been shown to favourably influence the clinical course of murine malaria. At least in theory, the favourable effect of artesunate on the clinical course of malaria [1-10] may thus in part result from stimulation of eryptosis.

Excessive eryptosis may, however, lead to anemia due to phagocytosis and subsequent removal of phosphatidylserine exposing erythrocytes. Anemia may be prevented as long as accelerated clearance of erythrocytes during stimulated eryptosis is outweighed by similarly increased formation of new erythrocytes [34]. Phosphatidylserine exposing erythrocytes may further bind to CXCL16/SR-PSO expressed by endothelial cells in the vascular wall [106] and may further stimulate blood clotting and thrombosis [107-109]. Accordingly, phosphatidylserine exposing erythrocytes may impair microcirculation [35, 107, 110-113]. The proeryptotic effect of artesunate may be particularly strong in clinical disorders with accelerated eryptosis, such as sepsis [114], fever [115], malaria [103, 104, 116], sickle cell disease [117], thalassemia [118, 119], Wilson's disease [120], iron deficiency [121] hepatic failure [122], malignancy [123], metabolic syndrome [124], diabetes [40, 125], dehydration [70], renal insufficiency [126], hemolytic uremic syndrome [127], hyperphosphatemia [79] and phosphate depletion [128]. Under those conditions the use of artesunate may be contraindicated.

\section{Conclusion}

Artesunate stimulates erythrocyte cell membrane scrambling, an effect at least partially due to increase of cytosolic $\mathrm{Ca}^{2+}$ activity, ceramide formation and oxidative stress.

\section{Disclosure Statement}

The authors of this manuscript state that they do not have any conflict of interests and nothing to disclose.

\section{Acknowledgements}

The authors acknowledge the meticulous preparation of the manuscript by Tanja Loch. The study was supported by the Deutsche Forschungsgemeinschaft and the Open Access Publishing Fund of Tuebingen University. 


\section{Cellular Physiology and Biochemistry}

\section{References}

1 Bukirwa H, Critchley J: Sulfadoxine-pyrimethamine plus artesunate versus sulfadoxine-pyrimethamine plus amodiaquine for treating uncomplicated malaria. Cochrane Database Syst Rev 2006;10.1002/14651858. CD004966.pub2CD004966.

2 Checkley AM, Whitty CJ: Artesunate, artemether or quinine in severe Plasmodium falciparum malaria? Expert Rev Anti Infect Ther 2007;5:199-204.

-3 Hess KM, Goad JA, Arguin PM: Intravenous artesunate for the treatment of severe malaria. Ann Pharmacother 2010;44:1250-1258.

4 Jones KL, Donegan S, Lalloo DG: Artesunate versus quinine for treating severe malaria. Cochrane Database Syst Rev 2007;10.1002/14651858.CD005967.pub2CD005967.

-5 Kurth F, Belard S, Basra A, Ramharter M: Pyronaridine-artesunate combination therapy for the treatment of malaria. Curr Opin Infect Dis 2011;24:564-569.

6 Morris CA, Duparc S, Borghini-Fuhrer I, Jung D, Shin CS, Fleckenstein L: Review of the clinical pharmacokinetics of artesunate and its active metabolite dihydroartemisinin following intravenous, intramuscular, oral or rectal administration. Malar J 2011;10:263.

7 Noubiap JJ: Shifting from quinine to artesunate as first-line treatment of severe malaria in children and adults: Saving more lives. J Infect Public Health 2014;10.1016/j.jiph.2014.04.007

8 Rosenthal PJ: Artesunate for the treatment of severe falciparum malaria. N Engl J Med 2008;358:18291836.

-9 Sinclair D, Donegan S, Isba R, Lalloo DG: Artesunate versus quinine for treating severe malaria. Cochrane Database Syst Rev 2012;6:CD005967.

10 Sirima SB, Gansane A: Artesunate-amodiaquine for the treatment of uncomplicated malaria. Expert Opin Investig Drugs 2007;16:1079-1085.

11 Efferth T, Romero MR, Wolf DG, Stamminger T, Marin JJ, Marschall M: The antiviral activities of artemisinin and artesunate. Clin Infect Dis 2008;47:804-811.

12 Dong HY, Wang ZF: Antitumor effects of artesunate on human breast carcinoma MCF-7 cells and IGF-IR expression in nude mice xenografts. Chin J Cancer Res 2014;26:200-207.

13 He RR, Zhou HJ: Progress in research on the anti-tumor effect of artesunate. Chin J Integr Med 2008;14:312-316.

14 Holien T, Olsen OE, Misund K, Hella H, Waage A, Ro TB, Sundan A: Lymphoma and myeloma cells are highly sensitive to growth arrest and apoptosis induced by artesunate. Eur J Haematol 2013;91:339-346.

15 Jiang W, Huang Y, Wang JP, Yu XY, Zhang LY: The synergistic anticancer effect of artesunate combined with allicin in osteosarcoma cell line in vitro and in vivo. Asian Pac J Cancer Prev 2013;14:4615-4619.

16 Jin M, Shen X, Zhao C, Qin X, Liu H, Huang L, Qiu Z, Liu Y: In vivo study of effects of artesunate nanoliposomes on human hepatocellular carcinoma xenografts in nude mice. Drug Deliv 2013;20:127-133.

-17 Karpel-Massler G, Westhoff MA, Kast RE, Dwucet A, Nonnenmacher L, Wirtz CR, Debatin KM, Halatsch ME: Artesunate enhances the antiproliferative effect of temozolomide on U87MG and A172 glioblastoma cell lines. Anticancer Agents Med Chem 2014;14:313-318.

18 Li Q Remich S, Miller SR, Ogutu B, Otieno W, Melendez V, Teja-Isavadharm P, Weina PJ, Hickman MR, Smith B, Polhemus M: Pharmacokinetic evaluation of intravenous artesunate in adults with uncomplicated falciparum malaria in Kenya: a phase II study. Malar J 2014;13:281.

19 Liu Y, Cui YF: Synergism of cytotoxicity effects of triptolide and artesunate combination treatment in pancreatic cancer cell lines. Asian Pac J Cancer Prev 2013;14:5243-5248.

20 Luo J, Zhu W, Tang Y, Cao H, Zhou Y, Ji R, Zhou X, Lu Z, Yang H, Zhang S, Cao J: Artemisinin derivative artesunate induces radiosensitivity in cervical cancer cells in vitro and in vivo. Radiat Oncol 2014;9:84.

21 Ma H, Yao Q, Zhang AM, Lin S, Wang XX, Wu L, Sun JG, Chen ZT: The effects of artesunate on the expression of EGFR and ABCG2 in A549 human lung cancer cells and a xenograft model. Molecules 2011;16:1055610569.

22 Mao ZG, Zhou J, Wang H, He DS, Xiao WW, Liao GZ, Qiu LB, Zhu YH, Wang HJ: Artesunate inhibits cell proliferation and decreases growth hormone synthesis and secretion in GH3 cells. Mol Biol Rep 2012;39:6227-6234. 
Alzoubi et al.: Artesunate-Induced Eryptosis

23 Papanikolaou X, Johnson S, Garg T, Tian E, Tytarenko R, Zhang Q, Stein C, Barlogie B, Epstein J, Heuck C: Artesunate overcomes drug resistance in multiple myeloma by inducing mitochondrial stress and noncaspase apoptosis. Oncotarget 2014;5:4118-4128.

24 Reichert S, Reinboldt V, Hehlgans S, Efferth T, Rodel C, Rodel F: A radiosensitizing effect of artesunate in glioblastoma cells is associated with a diminished expression of the inhibitor of apoptosis protein survivin. Radiother Oncol 2012;103:394-401.

25 Wang Y, Yang J, Chen L, Wang J, Wang Y, Luo J, Pan L, Zhang X: Artesunate induces apoptosis through caspase-dependent and -independent mitochondrial pathways in human myelodysplastic syndrome SKM-1 cells. Chem Biol Interact 2014;219C:28-36.

-26 Zhao F, Wang H, Kunda P, Chen X, Liu QL, Liu T: Artesunate exerts specific cytotoxicity in retinoblastoma cells via CD71. Oncol Rep 2013;30:1473-1482.

27 Zhou X, Sun WJ, Wang WM, Chen K, Zheng JH, Lu MD, Li PH, Zheng ZQ: Artesunate inhibits the growth of gastric cancer cells through the mechanism of promoting oncosis both in vitro and in vivo. Anticancer Drugs 2013;24:920-927.

28 Cheng R, Li C, Li C, Wei L, Li L, Zhang Y, Yao Y, Gu X, Cai W, Yang Z, Ma J, Yang X, Gao G: The artemisinin derivative artesunate inhibits corneal neovascularization by inducing ROS-dependent apoptosis in vascular endothelial cells. Invest Ophthalmol Vis Sci 2013;54:3400-3409.

29 Jiang Z, Chai J, Chuang HH, Li S, Wang T, Cheng Y, Chen W, Zhou D: Artesunate induces G0/G1 cell cycle arrest and iron-mediated mitochondrial apoptosis in A431 human epidermoid carcinoma cells. Anticancer Drugs 2012;23:606-613.

-30 Longxi P, Buwu F, Yuan W, Sinan G: Expression of p53 in the effects of artesunate on induction of apoptosis and inhibition of proliferation in rat primary hepatic stellate cells. PLoS One 2011;6:e26500.

-31 Zhou C, Pan W, Wang XP, Chen TS: Artesunate induces apoptosis via a Bak-mediated caspase-independent intrinsic pathway in human lung adenocarcinoma cells. J Cell Physiol 2012;227:3778-3786.

-32 Duranton C, Akkaya C, Brand VB, Tanneur V, Lang F, Huber SM: Artemisinin inhibits cation currents in malaria-infected human erythrocytes. Nanomedicine 2005;1:143-149.

-33 Lang PA, Kaiser S, Myssina S, Wieder T, Lang F, Huber SM: Role of Ca2+-activated K+ channels in human erythrocyte apoptosis. Am J Physiol Cell Physiol 2003;285:C1553-C1560.

34 Lang E, Qadri SM, Lang F: Killing me softly - suicidal erythrocyte death. Int J Biochem Cell Biol 2012;44:1236-1243.

35 Abed M, Towhid ST, Mia S, Pakladok T, Alesutan I, Borst O, Gawaz M, Gulbins E, Lang F: Sphingomyelinaseinduced adhesion of eryptotic erythrocytes to endothelial cells. Am J Physiol Cell Physiol 2012;303:C991999.

-36 Bhavsar SK, Bobbala D, Xuan NT, Foller M, Lang F: Stimulation of suicidal erythrocyte death by alpha-lipoic acid. Cell Physiol Biochem 2010;26:859-868.

37 Foller M, Feil S, Ghoreschi K, Koka S, Gerling A, Thunemann M, Hofmann F, Schuler B, Vogel J, Pichler B, Kasinathan RS, Nicolay JP, Huber SM, Lang F, Feil R: Anemia and splenomegaly in cGKI-deficient mice. Proc Natl Acad Sci USA 2008;105:6771-6776.

-38 Foller M, Mahmud H, Gu S, Wang K, Floride E, Kucherenko Y, Luik S, Laufer S, Lang F: Participation of leukotriene C(4) in the regulation of suicidal erythrocyte death. J Physiol Pharmacol 2009;60:135-143.

39 Lau IP, Chen H, Wang J, Ong HC, Leung KC, Ho HP, Kong SK: In vitro effect of CTAB- and PEG-coated gold nanorods on the induction of eryptosis/erythroptosis in human erythrocytes. Nanotoxicology 2012;6:847856.

40 Maellaro E, Leoncini S, Moretti D, Del Bello B, Tanganelli I, De Felice C, Ciccoli L: Erythrocyte caspase-3 activation and oxidative imbalance in erythrocytes and in plasma of type 2 diabetic patients. Acta Diabetol 2013;50:489-495.

41 Kucherenko Y, Zelenak C, Eberhard M, Qadri SM, Lang F: Effect of casein kinase 1alpha activator pyrvinium pamoate on erythrocyte ion channels. Cell Physiol Biochem 2012;30:407-417.

42 Zelenak C, Eberhard M, Jilani K, Qadri SM, Macek B, Lang F: Protein kinase CK1alpha regulates erythrocyte survival. Cell Physiol Biochem 2012;29:171-180.

43 Bhavsar SK, Gu S, Bobbala D, Lang F: Janus kinase 3 is expressed in erythrocytes, phosphorylated upon energy depletion and involved in the regulation of suicidal erythrocyte death. Cell Physiol Biochem 2011;27:547-556. 
44 Klarl BA, Lang PA, Kempe DS, Niemoeller OM, Akel A, Sobiesiak M, Eisele K, Podolski M, Huber SM, Wieder T, Lang F: Protein kinase C mediates erythrocyte "programmed cell death" following glucose depletion. Am J Physiol Cell Physiol 2006;290:C244-C253.

45 Gatidis S, Zelenak C, Fajol A, Lang E, Jilani K, Michael D, Qadri SM, Lang F: p38 MAPK activation and function following osmotic shock of erythrocytes. Cell Physiol Biochem 2011;28:1279-1286.

-46 Foller M, Sopjani M, Koka S, Gu S, Mahmud H, Wang K, Floride E, Schleicher E, Schulz E, Munzel T, Lang F: Regulation of erythrocyte survival by AMP-activated protein kinase. FASEB J 2009;23:1072-1080.

47 Zelenak C, Foller M, Velic A, Krug K, Qadri SM, Viollet B, Lang F, Macek B: Proteome analysis of erythrocytes lacking AMP-activated protein kinase reveals a role of PAK2 kinase in eryptosis. J Proteome Res 2011;10:1690-1697.

48 Lupescu A, Shaik N, Jilani K, Zelenak C, Lang E, Pasham V, Zbidah M, Plate A, Bitzer M, Foller M, Qadri SM, Lang F: Enhanced erythrocyte membrane exposure of phosphatidylserine following sorafenib treatment: an in vivo and in vitro study. Cell Physiol Biochem 2012;30:876-888.

49 Shaik N, Lupescu A, Lang F: Sunitinib-sensitive suicidal erythrocyte death. Cell Physiol Biochem 2012;30:512-522.

50 Abed M, Towhid ST, Shaik N, Lang F: Stimulation of suicidal death of erythrocytes by rifampicin. Toxicology 2012;302:123-128.

51 Bottger E, Multhoff G, Kun JF, Esen M: Plasmodium falciparum-infected erythrocytes induce granzyme B by NK cells through expression of host-Hsp70. PLoS One 2012;7:e33774.

52 Firat U, Kaya S, Cim A, Buyukbayram H, Gokalp O, Dal MS, Tamer MN: Increased caspase-3 immunoreactivity of erythrocytes in STZ diabetic rats. Exp Diabetes Res 2012;2012:316384.

53 Ganesan S, Chaurasiya ND, Sahu R, Walker LA, Tekwani BL: Understanding the mechanisms for metabolism-linked hemolytic toxicity of primaquine against glucose 6-phosphate dehydrogenase deficient human erythrocytes: evaluation of eryptotic pathway. Toxicology 2012;294:54-60.

54 Gao M, Cheung KL, Lau IP, Yu WS, Fung KP, Yu B, Loo JF, Kong SK: Polyphyllin D induces apoptosis in human erythrocytes through $\mathrm{Ca}(2)(+)$ rise and membrane permeabilization. Arch Toxicol 2012;86:741-752.

55 Jilani K, Lupescu A, Zbidah M, Abed M, Shaik N, Lang F: Enhanced Apoptotic Death of Erythrocytes Induced by the Mycotoxin Ochratoxin A. Kidney Blood Press Res 2012;36:107-118.

56 Zbidah M, Lupescu A, Jilani K, Lang F: Stimulation of suicidal erythrocyte death by fumagillin. Basic Clin Pharmacol Toxicol 2013;112:346-351.

57 Kucherenko YV, Lang F: Inhibitory Effect of Furosemide on Non-Selective Voltage-Independent Cation Channels in Human Erythrocytes. Cell Physiol Biochem 2012;30:863-875.

58 Zelenak C, Pasham V, Jilani K, Tripodi PM, Rosaclerio L, Pathare G, Lupescu A, Faggio C, Qadri SM, Lang F: Tanshinone IIA stimulates erythrocyte phosphatidylserine exposure. Cell Physiol Biochem 2012;30:282294.

59 Lupescu A, Jilani K, Zbidah M, Lang F: Induction of apoptotic erythrocyte death by rotenone. Toxicology 2012;300:132-137.

60 Lupescu A, Jilani K, Zelenak C, Zbidah M, Qadri SM, Lang F: Hexavalent chromium-induced erythrocyte membrane phospholipid asymmetry. Biometals 2012;25:309-318.

61 Polak-Jonkisz D, Purzyc L: Ca Influx versus Efflux during Eryptosis in Uremic Erythrocytes. Blood Purif 2012;34:209-210.

62 Qian EW, Ge DT, Kong SK: Salidroside protects human erythrocytes against hydrogen peroxide-induced apoptosis. J Nat Prod 2012;75:531-537.

63 Shaik N, Zbidah M, Lang F: Inhibition of $\mathrm{Ca}(2+)$ entry and suicidal erythrocyte death by naringin. Cell Physiol Biochem 2012;30:678-686.

64 Vota DM, Maltaneri RE, Wenker SD, Nesse AB, Vittori DC: Differential erythropoietin action upon cells induced to eryptosis by different agents. Cell Biochem Biophys 2013;65:145-157.

65 Zbidah M, Lupescu A, Shaik N, Lang F: Gossypol-induced suicidal erythrocyte death. Toxicology 2012;302:101-105.

66 Lang E, Qadri SM, Jilani K, Zelenak C, Lupescu A, Schleicher E, Lang F: Carbon monoxide-sensitive apoptotic death of erythrocytes. Basic Clin Pharmacol Toxicol 2012;111:348-355.

67 Abed M, Zoubi KA, Theurer M, Lang F: Effect of dermaseptin on erythrocytes. Basic Clin Pharmacol Toxicol 2013;113:347-352. 
68 Ahmed MS, Langer H, Abed M, Voelkl J, Lang F: The uremic toxin acrolein promotes suicidal erythrocyte death. Kidney Blood Press Res 2013;37:158-167.

69 Ghashghaeinia M, Cluitmans JC, Toulany M, Saki M, Koberle M, Lang E, Dreischer P, Biedermann T, Duszenko M, Lang F, Bosman GJ, Wieder T: Age Sensitivity of NFkappaB Abundance and Programmed Cell Death in Erythrocytes Induced by NFkappaB Inhibitors. Cell Physiol Biochem 2013;32:801-813.

70 Abed M, Feger M, Alzoubi K, Pakladok T, Frauenfeld L, Geiger C, Towhid ST, Lang F: Sensitization of erythrocytes to suicidal erythrocyte death following water deprivation. Kidney Blood Press Res 2013;37:567-578.

71 Alzoubi K, Honisch S, Abed M, Lang F: Triggering of Suicidal Erythrocyte Death by Penta-O-galloyl-beta-dglucose. Toxins (Basel) 2014;6:54-65.

72 Jilani K, Lang F: Carmustine-induced phosphatidylserine translocation in the erythrocyte membrane. Toxins (Basel) 2013;5:703-716.

73 Jilani K, Enkel S, Bissinger R, Almilaji A, Abed M, Lang F: Fluoxetine induced suicidal erythrocyte death. Toxins (Basel) 2013;5:1230-1243.

74 Lupescu A, Bissinger R, Jilani K, Lang F: Triggering of suicidal erythrocyte death by celecoxib. Toxins (Basel) 2013;5:1543-1554.

75 Lupescu A, Jilani K, Zbidah M, Lang F: Patulin-induced suicidal erythrocyte death. Cell Physiol Biochem 2013;32:291-299.

76 Arnold M, Lang E, Modicano P, Bissinger R, Faggio C, Abed M, Lang F: Effect of nitazoxanide on erythrocytes. Basic Clin Pharmacol Toxicol 2014;114:421-426.

77 Oswald G, Alzoubi K, Abed M, Lang F: Stimulation of suicidal erythrocyte death by ribavirin. Basic Clin Pharmacol Toxicol 2014;114:311-317.

78 Bissinger R, Malik A, Jilani K, Lang F: Triggering of Erythrocyte Cell Membrane Scrambling by Salinomycin. Basic Clin Pharmacol Toxicol 2014;10.1111/bcpt.12250

79 Voelkl J, Alzoubi K, Mamar AK, Ahmed MS, Abed M, Lang F: Stimulation of suicidal erythrocyte death by increased extracellular phosphate concentrations. Kidney Blood Press Res 2013;38:42-51.

-80 Lupescu A, Jilani K, Zelenak C, Zbidah M, Shaik N, Lang F: Induction of programmed erythrocyte death by gambogic acid. Cell Physiol Biochem 2012;30:428-438.

81 Abed M, Herrmann T, Alzoubi K, Pakladok T, Lang F: Tannic Acid induced suicidal erythrocyte death. Cell Physiol Biochem 2013;32:1106-1116.

82 Shaik N, Alhourani E, Bosc A, Liu G, Towhid S, Lupescu A, Lang F: Stimulation of suicidal erythrocyte death by ipratropium bromide. Cell Physiol Biochem 2012;30:1517-1525.

83 Jilani K, Lupescu A, Zbidah M, Shaik N, Lang F: Withaferin A-stimulated Ca2+ entry, ceramide formation and suicidal death of erythrocytes. Toxicol In Vitro 2013;27:52-58.

-84 Qadri SM, Mahmud H, Foller M, Lang F: Thymoquinone-induced suicidal erythrocyte death. Food Chem Toxicol 2009; 47:1545-1549.

85 Jilani K, Abed M, Zelenak C, Lang E, Qadri SM, Lang F: Triggering of erythrocyte cell membrane scrambling by ursolic acid. J Nat Prod 2011;74:2181-2186.

86 Zbidah M, Lupescu A, Herrmann T, Yang W, Foller M, Jilani K, Lang F: Effect of honokiol on erythrocytes. Toxicol In Vitro 2013;27:1737-1745.

87 Bissinger R, Modicano P, Alzoubi K, Honisch S, Faggio C, Abed M, Lang F: Effect of saponin on erythrocytes. Int J Hematol 2014;100:51-59.

88 Zbidah M, Lupescu A, Jilani K, Fajol A, Michael D, Qadri SM, Lang F: Apigenin-induced suicidal erythrocyte death. J Agric Food Chem 2012;60:533-538.

89 Jilani K, Qadri SM, Zelenak C, Lang F: Stimulation of suicidal erythrocyte death by oridonin. Arch Biochem Biophys 2011;511:14-20.

-90 Sinha A, Singh A, Satchidanandam V, Natarajan K: Impaired generation of reactive oxygen species during differentiation of dendritic cells (DCs) by Mycobacterium tuberculosis secretory antigen (MTSA) and subsequent activation of MTSA-DCs by mycobacteria results in increased intracellular survival. J Immunol 2006;177:468-478.

91 Li Y, Feng L, Li Y, Jiang W, Shan N, Wang X: Artesunate possesses anti-leukemia properties that can be enhanced by arsenic trioxide. Leuk Lymphoma 2014;55:1366-1372.

-92 Efferth T, Giaisi M, Merling A, Krammer PH, Li-Weber M: Artesunate induces ROS-mediated apoptosis in doxorubicin-resistant T leukemia cells. PLoS One 2007;2:e693. 
Alzoubi et al.: Artesunate-Induced Eryptosis

93 Sieber S, Gdynia G, Roth W, Bonavida B, Efferth T: Combination treatment of malignant B cells using the anti-CD20 antibody rituximab and the anti-malarial artesunate. Int J Oncol 2009;35:149-158.

$\$ 94$ Du JH, Zhang HD, Ma ZJ, Ji KM: Artesunate induces oncosis-like cell death in vitro and has antitumor activity against pancreatic cancer xenografts in vivo. Cancer Chemother Pharmacol 2010;65:895-902.

-95 Harrison HE, Bunting H, Ordway NK, Albrink WS: The Pathogenesis of the Renal Injury Produced in the Dog by Hemoglobin or Methemoglobin. J Exp Med 1947;86:339-356.

-96 Foller M, Bobbala D, Koka S, Huber SM, Gulbins E, Lang F: Suicide for survival--death of infected erythrocytes as a host mechanism to survive malaria. Cell Physiol Biochem 2009;24:133-140.

-97 Duranton C, Huber S, Tanneur V, Lang K, Brand V, Sandu C, Lang F: Electrophysiological properties of the Plasmodium Falciparum-induced cation conductance of human erythrocytes. Cell Physiol Biochem 2003;13:189-198.

-98 Kirk K: Membrane transport in the malaria-infected erythrocyte. Physiol Rev 2001;81:495-537.

-99 Ayi K, Giribaldi G, Skorokhod A, Schwarzer E, Prendergast PT, Arese P: 16alpha-bromoepiandrosterone, an antimalarial analogue of the hormone dehydroepiandrosterone, enhances phagocytosis of ring stage parasitized erythrocytes: a novel mechanism for antimalarial activity. Antimicrob Agents Chemother 2002;46:3180-3184.

100 Ayi K, Turrini F, Piga A, Arese P: Enhanced phagocytosis of ring-parasitized mutant erythrocytes: a common mechanism that may explain protection against falciparum malaria in sickle trait and betathalassemia trait. Blood 2004;104:3364-3371.

101 Cappadoro M, Giribaldi G, O'Brien E, Turrini F, Mannu F, Ulliers D, Simula G, Luzzatto L, Arese P: Early phagocytosis of glucose-6-phosphate dehydrogenase (G6PD)-deficient erythrocytes parasitized by Plasmodium falciparum may explain malaria protection in G6PD deficiency. Blood 1998;92:2527-2534.

102 Koka S, Foller M, Lamprecht G, Boini KM, Lang C, Huber SM, Lang F: Iron deficiency influences the course of malaria in Plasmodium berghei infected mice. Biochem Biophys Res Commun 2007;357:608-614.

103 Koka S, Huber SM, Boini KM, Lang C, Foller M, Lang F: Lead decreases parasitemia and enhances survival of Plasmodium berghei-infected mice. Biochem Biophys Res Commun 2007;363:484-489.

104 Koka S, Lang C, Boini KM, Bobbala D, Huber SM, Lang F: Influence of chlorpromazine on eryptosis, parasitemia and survival of Plasmodium berghe infected mice. Cell Physiol Biochem 2008;22:261-268.

105 Koka S, Lang C, Niemoeller OM, Boini KM, Nicolay JP, Huber SM, Lang F: Influence of NO synthase inhibitor L-NAME on parasitemia and survival of Plasmodium berghei infected mice. Cell Physiol Biochem 2008;21:481-488.

106 Borst O, Abed M, Alesutan I, Towhid ST, Qadri SM, Foller M, Gawaz M, Lang F: Dynamic adhesion of eryptotic erythrocytes to endothelial cells via CXCL16/SR-PSOX. Am J Physiol Cell Physiol 2012;302:C644-C651.

107 Andrews DA, Low PS: Role of red blood cells in thrombosis. Curr Opin Hematol 1999;6:76-82.

108 Chung SM, Bae ON, Lim KM, Noh JY, Lee MY, Jung YS, Chung JH: Lysophosphatidic acid induces thrombogenic activity through phosphatidylserine exposure and procoagulant microvesicle generation in human erythrocytes. Arterioscler Thromb Vasc Biol 2007;27:414-421.

109 Zwaal RF, Comfurius P, Bevers EM: Surface exposure of phosphatidylserine in pathological cells. Cell Mol Life Sci 2005;62:971-988.

110 Closse C, Dachary-Prigent J, Boisseau MR: Phosphatidylserine-related adhesion of human erythrocytes to vascular endothelium. Br J Haematol 1999;107:300-302.

111 Gallagher PG, Chang SH, Rettig MP, Neely JE, Hillery CA, Smith BD, Low PS: Altered erythrocyte endothelial adherence and membrane phospholipid asymmetry in hereditary hydrocytosis. Blood 2003;101:46254627.

112 Pandolfi A, Di Pietro N, Sirolli V, Giardinelli A, Di Silvestre S, Amoroso L, Di Tomo P, Capani F, Consoli A, Bonomini M: Mechanisms of uremic erythrocyte-induced adhesion of human monocytes to cultured endothelial cells. J Cell Physiol 2007;213:699-709.

113 Wood BL, Gibson DF, Tait JF: Increased erythrocyte phosphatidylserine exposure in sickle cell disease: flow-cytometric measurement and clinical associations. Blood 1996;88:1873-1880.

-114 Kempe DS, Akel A, Lang PA, Hermle T, Biswas R, Muresanu J, Friedrich B, Dreischer P, Wolz C, Schumacher U, Peschel A, Gotz F, Doring G, Wieder T, Gulbins E, Lang F: Suicidal erythrocyte death in sepsis. J Mol Med (Berl) 2007;85:273-281. 
115 Foller M, Braun M, Qadri SM, Lang E, Mahmud H, Lang F: Temperature sensitivity of suicidal erythrocyte death. Eur J Clin Invest 2010;40:534-540.

116 Totino PR, Daniel-Ribeiro CT, Ferreira-da-Cruz Mde F: Refractoriness of eryptotic red blood cells to Plasmodium falciparum infection: a putative host defense mechanism limiting parasitaemia. PLoS One 2011;6:e26575.

117 Weiss E, Cytlak UM, Rees DC, Osei A, Gibson JS: Deoxygenation-induced and Ca(2+) dependent phosphatidylserine externalisation in red blood cells from normal individuals and sickle cell patients. Cell Calcium 2012;51:51-56.

118 Basu S, Banerjee D, Chandra S, Chakrabarti A: Eryptosis in hereditary spherocytosis and thalassemia: role of glycoconjugates. Glycoconj J 2010;27:717-722.

119 Ibrahim HA, Fouda MI, Yahya RS, Abousamra NK, Abd Elazim RA: Erythrocyte phosphatidylserine exposure in beta-thalassemia. Lab Hematol 2014;20:9-14.

120 Lang PA, Schenck M, Nicolay JP, Becker JU, Kempe DS, Lupescu A, Koka S, Eisele K, Klarl BA, Rubben H, Schmid KW, Mann K, Hildenbrand S, Hefter H, Huber SM, Wieder T, Erhardt A, Haussinger D, Gulbins E, Lang F: Liver cell death and anemia in Wilson disease involve acid sphingomyelinase and ceramide. Nat Med 2007;13:164-170.

121 Kempe DS, Lang PA, Duranton C, Akel A, Lang KS, Huber SM, Wieder T, Lang F: Enhanced programmed cell death of iron-deficient erythrocytes. FASEB J 2006;20:368-370.

122 Lang E, Gatidis S, Freise NF, Bock H, Kubitz R, Lauermann C, Orth HM, Klindt C, Schuier M, Keitel V, Reich M, Liu G, Schmidt S, Xu HC, Qadri SM, Herebian D, Pandyra AA, Mayatepek E, Gulbins E, Lang F, Haussinger D, Lang KS, Foller M, Lang PA: Conjugated bilirubin triggers anemia by inducing erythrocyte death. Hepatology 2014;10.1002/hep.27338

123 Qadri SM, Mahmud H, Lang E, Gu S, Bobbala D, Zelenak C, Jilani K, Siegfried A, Foller M, Lang F: Enhanced suicidal erythrocyte death in mice carrying a loss-of-function mutation of the adenomatous polyposis coli gene. J Cell Mol Med 2012;16:1085-1093.

124 Zappulla D: Environmental stress, erythrocyte dysfunctions, inflammation, and the metabolic syndrome: adaptations to CO2 increases? J Cardiometab Syndr 2008;3:30-34.

125 Calderon-Salinas JV, Munoz-Reyes EG, Guerrero-Romero JF, Rodriguez-Moran M, Bracho-Riquelme RL, Carrera-Gracia MA, Quintanar-Escorza MA: Eryptosis and oxidative damage in type 2 diabetic mellitus patients with chronic kidney disease. Mol Cell Biochem 2011;357:171-179.

126 Abed M, Artunc F, Alzoubi K, Honisch S, Baumann D, Foller M, Lang F: Suicidal erythrocyte death in endstage renal disease. J Mol Med (Berl) 2014;92:871-879.

-127 Lang PA, Beringer O, Nicolay JP, Amon O, Kempe DS, Hermle T, Attanasio P, Akel A, Schafer R, Friedrich B, Risler T, Baur M, Olbricht CJ, Zimmerhackl LB, Zipfel PF, Wieder T, Lang F: Suicidal death of erythrocytes in recurrent hemolytic uremic syndrome. J Mol Med (Berl) 2006;84:378-388.

128 Birka C, Lang PA, Kempe DS, Hoefling L, Tanneur V, Duranton C, Nammi S, Henke G, Myssina S, Krikov M, Huber SM, Wieder T, Lang F: Enhanced susceptibility to erythrocyte "apoptosis" following phosphate depletion. Pflugers Arch 2004;448:471-477. 